\title{
SELF-EMPLOYMENT AND BUSINESS CYCLES: SEARCHING FOR ASYMMETRIES IN A PANEL OF 23 OECD COUNTRIES
}

\author{
Mónica CARMONA ${ }^{1}$, Emilio CONGREGADO ${ }^{2}$, \\ Antonio A. GOLPE ${ }^{3}$, Jesus IGLESIAS ${ }^{4}$ \\ ${ }^{1}$ Department of Business Administration and Marketing, University of Huelva, Spain \\ ${ }^{2,3,4}$ Department of Economics, University of Huelva, Spain \\ E-mails: ${ }^{1}$ monica@uhu.es; ${ }^{2}$ congregado@uhu.es; \\ 3antonio.golpe@dehie.uhu.es (correspondingautor); ${ }^{4}$ jesus.iglesias@dege.uhu.es
}

Received 21 November 2013; accepted 28 November 2014

\begin{abstract}
The aim of this work is to identify whether the bidirectional relationship between entrepreneurship cycles and output gaps is asymmetric depending on the phase of the business cycle. To this end, we employ a panel threshold regression model in which different relations can prevail in each regime, defined by the values of the threshold variable. The findings of this article qualify previous empirical results. In particular, our estimates provide support for the existence of different responses - both in terms of sign and magnitude - of cyclical self-employment to output growth and of output growth to cyclical self-employment, depending on the value of the threshold variable. The result is highly important for policy makers and practitioners given that whether they ignore the asymmetric impact that an entrepreneurship promotion policy action might have on the real economy, the action might lead to unexpected effects.
\end{abstract}

Keywords: entrepreneurship, self-employment, business cycles, panel threshold models, OECD, asymmetries.

JEL Classification: L26, J23, E32, C23.

\section{Introduction}

The re-examination of the relationships between different macroeconomic variables including entrepreneurship - and business cycles has become a hot policy issue at the time of writing because the ineffectiveness of the traditional stabilisation policies and the lack of confidence in the old active labour market policies. This fact has led to the search for alternative solutions to combat both stagnation and unemployment.

Entrepreneurship is a promising candidate in this respect, particularly if researchers can provide not only theoretical propositions but also robust evidence for how positive shocks in entrepreneurship lead to an expansionary phase of the business cycle in which case policies to promote self-employment might become a key pillar of any anti-crisis strategy. 
Theoretical models posit that entrepreneurship could be either pro-cyclical or acyclical ${ }^{1}$. In addition, arguments for counter-cyclicality are also possible: economic downturns can push people into self-employment, not only because the lack of paid-employment opportunities reduces the opportunity cost of this occupation ${ }^{2}$ but also because of the higher availability of second-hand capital equipment during recessions (Binks, Jennings 1986). Thus, downturns might also induce increases in the rate of necessity entrepreneurs although it might reduce the rate of opportunity entrepreneurs. All things considered, propositions derived from theoretical models tend to agree with the basic prediction of pro-cyclicality but tend to diverge with regard to whether the relationship is lagged, led or contemporaneous, as well as on the definition of entrepreneurship. In this context, we must recognise the need to discriminate among theories and propositions and shed new light on this relationship. The availability of robust (and conclusive) empirical work on this relationship would provide the ideal tool to solve any controversial matter of this type.

However, the relationship between self-employment and GDP cycles is unfortunately far from being solidly sustained by robust empirical results. On the contrary, researchers have tested the relationship in a variety of ways: from controlling business cycle effects in empirical works with individual data on the determinants of entry (survival) into selfemployment to time-series studies at the aggregate level. The latter include a handful of studies that have explored the relationship between output and entrepreneurship, relating the level of activity in the goods and services market to the level of entrepreneurship over the cycle. Taken together, these works offers inconclusive evidence that does not in any way contribute to resolving the current puzzle about this relationship.

In general, most of the previous empirical literature model the interaction between selfemployment and output growth with a linear reaction function that is, by construction, symmetric. However, controlling for asymmetries by using non-linear methodologies is an advisable strategy given that: i) some theories and theoretical propositions suggest that different types of effects (in terms of intensity, sign or both) can be expected depending on the phase of the business cycle or on the situation of the self-employment sector ${ }^{3}$; ii) we should account for the possibility to calibrate the effect of an entrepreneurship policy action on the state of the economy ${ }^{4}$ or the effect of counter-recessionary policies on self-employment, depending on the situation of the self-employment sector; and iii) ignoring asymmetry when it is present produces not only bad forecasts but also errone-

\footnotetext{
${ }^{1}$ See Parker (2012) for a survey.

2 The literature refers to this phenomenon by using different terms such as the "recession-push" effect, "turning unemployment into self-employment" (Baumgartner, Caliendo 2008), "necessity-" driven entrepreneurs (Reynolds et al. 2001), the "refugee-effect" (Carree, Thurik 2003) or even as the entry into self-employment as a "last resort".

${ }^{3}$ Theoretical rationales in favour of this argument may be summarised in the prosperity-pull and recession-push hypotheses.

${ }^{4}$ Policy makers and practitioners ignoring the asymmetric impact that an entrepreneurship promotion policy action might have on the real economy depending on the phase of the business cycle where the action takes place might lead not only to ineffectiveness but could even have effects contrary to those desired.
} 
ous inferences in hypothesis testing. For these reasons, the present work instead accounts for non-linearity by adopting a panel threshold regression model (Hansen 1999).

The remainder of this article is structured as follows. The next section briefly discusses the empirical evidence on entrepreneurship and the business cycle. The second section presents the different specifications and the estimation strategy. The third section describes the data and presents the results. The fourth section discusses the results. The final section concludes.

\section{A selective review of empirical literature}

This section provides a selective review of the recent contributions to the empirical literature on the evolution of GDP and self-employment. In general, most previous works focused on either examining the direction of the causality between business ownership and economic performance (usually tested by using Granger causality tests) or testing the two-way relationship between these two variables. Overall, the empirical results of this body of literature provide sometimes, conflicting results (see Dejardin 2011). The lack of consensus on the existence of this relationship and its direction is due to the use of different data sets and alternative econometric approaches. In Table 1, a selective summary of these empirical works is presented.

A general observation of the findings reported in this table enables us to state that the results have been mixed. On the one hand, in terms of the existence of the relationship, some studies reject it or provide weak evidence for the relationship, whereas others only focus on the causality between the two variables. Some works conclude that causality runs from entrepreneurship to economic growth (Hartog et al. 2010; Koellinger, Thurik 2012), whereas others state that it runs from economic growth to business ownership (Carmona et al. 2012; Aubrey et al. 2013); some studies suggest that there is no causality and in some cases even find bidirectional causality between these two variables (Parker et al. 2012). On the other hand, the sign of the estimated relationship seems to depend on whether the relationship is estimated in levels (i.e., estimations with trend components capturing a generally positive long-term relationship); when the estimation of the relationship is done by using de-trended components, negative relationships seem to prevail. In general, it could be argued that when time-series analysis has been applied to a single data set, results seem to be mixed as shown by the works included in the upper part of the table devoted to time-series analyses. We can classify the first empirical attempts to study this relationship in this group: they were time-series analyses using short time series with low frequencies (see Parker 1996 or Cowling, Mitchell 1997). Later, thanks to the valuable work of some researchers and institutions ${ }^{5}$, the re-examination of this relationship became possible. These efforts resulted in the availability of long time-series and comparable cross-country data, which allowed for the use of new econometric approaches (panel data models). In this first generation of studies with panel data, the use of pooled regression and fixed effect models was prevalent. Recently, dynamic panel data models have also been employed (Koellinger, Thurik 2012; Acs et al. 2012).

\footnotetext{
${ }^{5}$ We refer here to the OECD, Eurostat, or the pioneering effort in harmonisation carried out by van Stel et al. (2010) in the EIM.
} 
M. Carmona et al. Self-employment and business cycles: searching for asymmetries in a panel ...

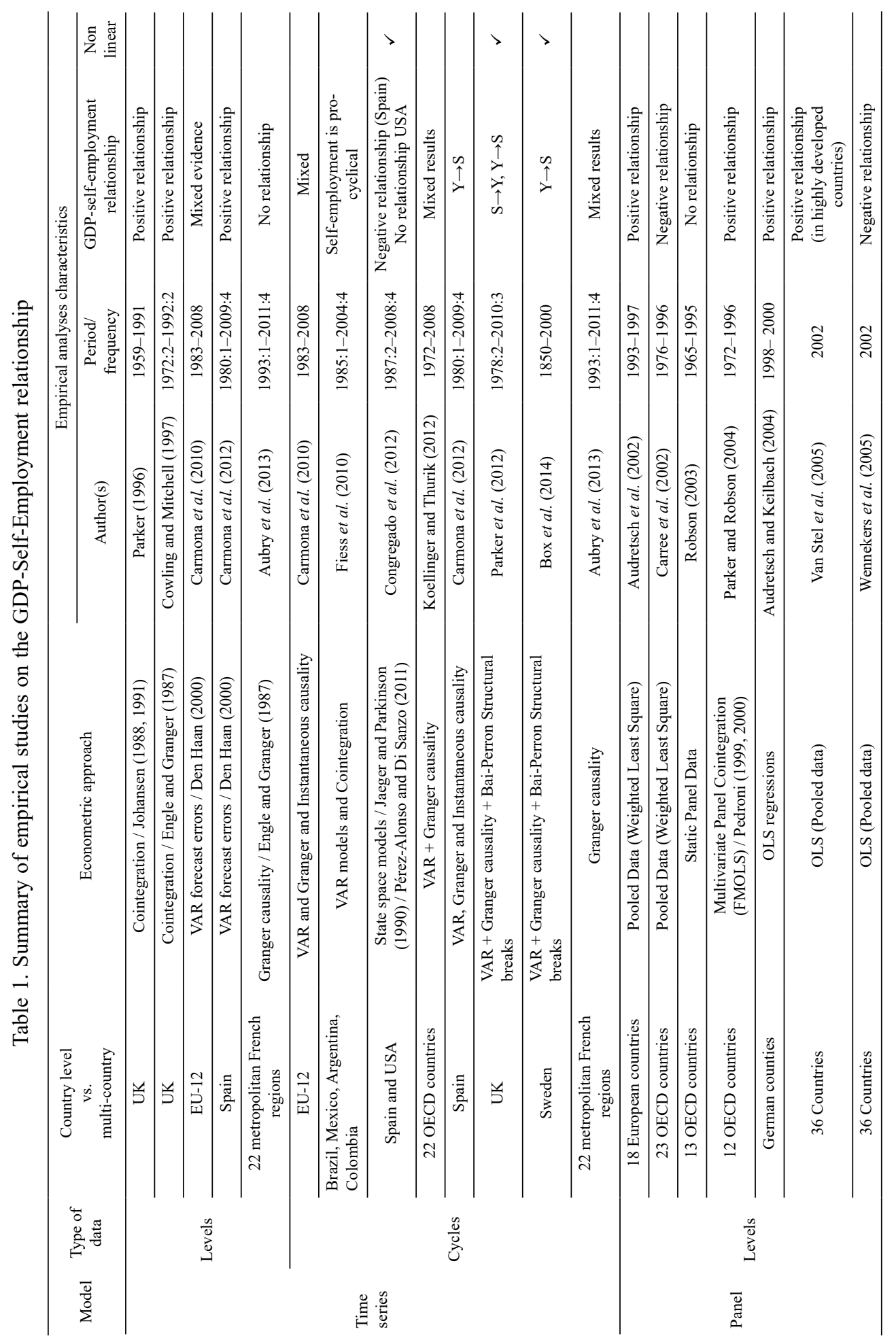




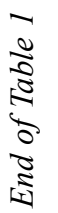

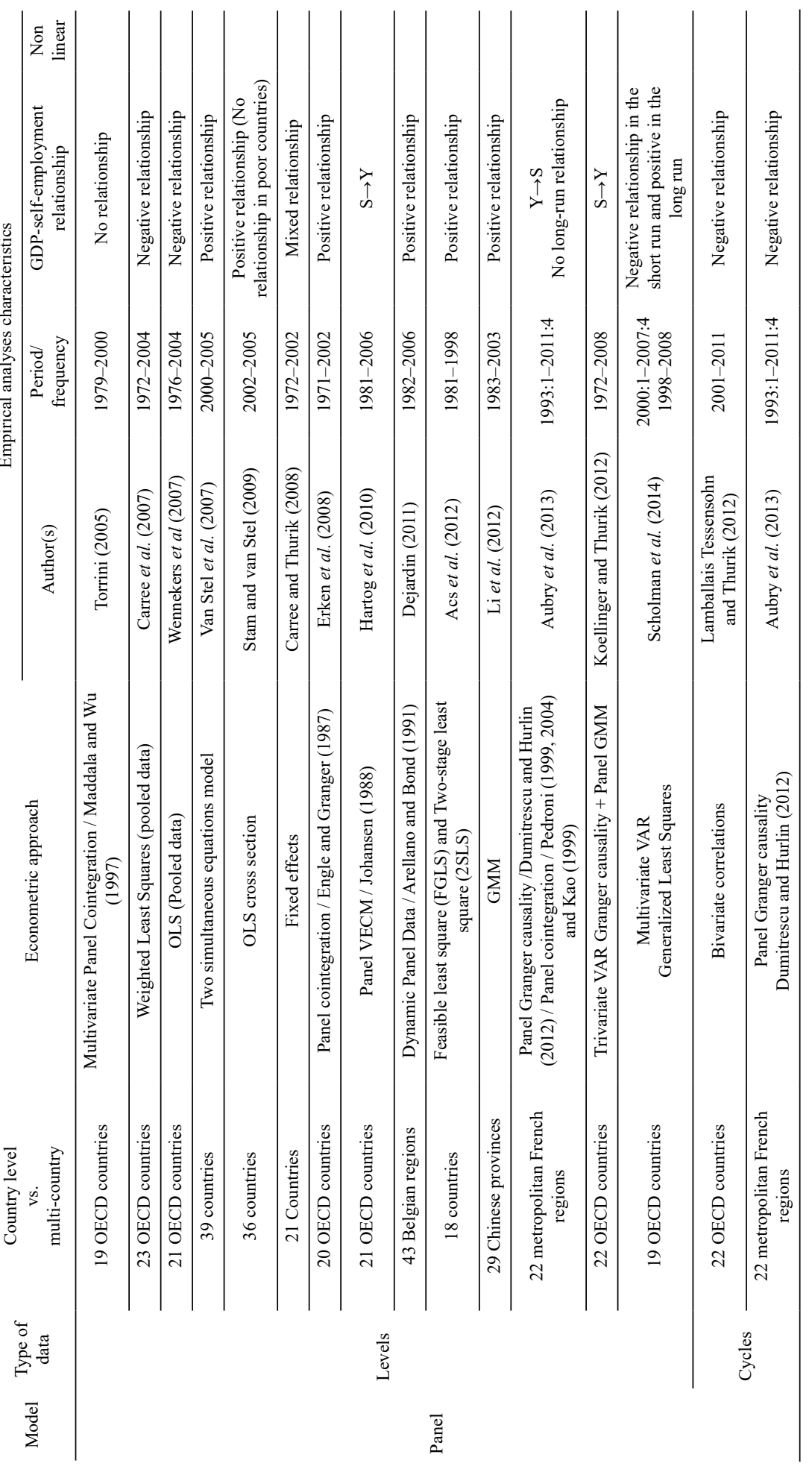


A common element in the studies reviewed until now is that they only analyse the relationship of the trend, not its cyclical components. However, the recent availability of longer and high-frequency time series has allowed for the analysis of the relationship between the fluctuations in output and the cyclical component of business ownership in both country-specific and cross-country studies (see Fiess et al. 2010; Carmona et al. 2010; Congregado et al. 2012; Koellinger, Thurik 2012; Parker et al. 2012; Scholman et al. 2014; Aubry et al. 2013 as examples of the former). In a strict sense, only these works may be regarded as studies on the relationship between business creation and business cycles ${ }^{6}$. Finally, and because of the sensitivity of the relationship analysis result to the sampling period even in country-specific studies, it is important to account for the possible existence of asymmetries in the relationship - i.e., allowing for nonlinearities in the relationship. Let us remember that ignoring asymmetry when it is present might produce erroneous inferences in hypothesis testing. Only a few studies have studied the possibility of a nonlinear relationship in country-specific analyses - see Parker et al. (2012) for the UK, Congregado et al. (2012) for Spain and the US and Box et al. (2014) for Sweden. However, to the best of our knowledge, no cross-country studies that account for nonlinearity exist at the present time. To fill this gap, the next section investigates whether self-employment rates have asymmetric responses to output gap, depending on the phase of the business cycle and analyses whether a shock in the self-employment rate has a different effect on the real economy depending on the phase of the business cycle or the cyclical evolution of the self-employment sector.

\section{Model specification}

As we mentioned above, in this section, we investigate not only whether cyclical selfemployment influences subsequent output growth but also the reverse effect of business cycle fluctuations on cyclical self-employment. The relationship between cyclical real output and self-employment rates involves estimating the following equation:

or its reverse:

$$
\Delta s_{i t}=\mu_{i}+\beta \Delta y_{i t}
$$

$$
\Delta y_{i t}=\mu_{i}^{\prime}+\beta^{\prime} \Delta s_{i t},
$$

where $\Delta s_{i t}$ and $\Delta y_{i t}$ are the growth rates of self-employment and output, respectively, in period $t$ for country $i$.

The previous two-way relationships described by equations $1 \mathrm{a}$ and $1 \mathrm{~b}$ can be rewritten as a "gap" specification in which output and self-employment are measured in terms of the cyclical components or deviations from long-term trends. In general, this empirical relationship can be represented by the following set of equations:

$$
\begin{aligned}
& y_{i t}^{c}=y_{i t}-y_{i t}^{n} ; \\
& s_{i t}^{c}=s_{i t}-s_{i t}^{n} ;
\end{aligned}
$$

\footnotetext{
${ }^{6} \mathrm{We}$ are conscious of the existence of an extant body of empirical literature on the relationship between unemployment and self-employment cycles at the aggregate level but the study of this relationship is out of the scope of this article.
} 


$$
y_{i t}^{c}=\mu_{i}+\beta s_{i t}^{c}+\varepsilon_{i t},
$$

or, alternatively, by:

$$
s_{i t}^{c}=\mu_{i}^{\prime}+\beta^{\prime} y_{i t}^{c}+\varepsilon_{i t},
$$

where $y_{i t}^{c}$ captures the cyclical level of output (output gap), $y_{i t}$ is the log of the actual output, and $y_{i t}^{n}$ is the trend level of the output; correspondingly, $s_{i t}^{c}$ represents the cyclical self-employment rate (self-employment gap), $s_{i t}$ is the observed self-employment rate, and $s_{i t}^{n}$ is the natural self-employment rate. In contrast to Equation (1), these two Equations (4a and $4 \mathrm{~b}$ ) require information about self-employment and output trends, which are directly unobservable. Because it is the most common practice, we will consider the Hodrick-Prescott filter (Hodrick, Prescott 1997).

An alternative specification for the baseline models (4a and $4 b$ ) is given by:

$$
\begin{aligned}
& y_{i t}^{c}=\mu_{i}+\beta_{s} s_{i t-1}^{c}+\beta_{u} u_{i t}^{c}+\varepsilon_{i t} ; \\
& s_{i t}^{c}=\mu_{i}^{\prime}+\beta_{y}^{\prime} y_{i t-1}^{c}+\beta_{u}^{\prime} u_{i t}^{c}+\varepsilon_{i t},
\end{aligned}
$$

where the new term $u_{i t}^{c}$ is included to capture the inertia of the series that is not captured by $s_{i t}^{c}$ and $y_{i t}^{c}$, respectively ${ }^{7}$.

\subsection{Asymmetry}

Although there is a substantial body of evidence supporting the notion that time series exhibit asymmetric behaviour over business cycles, the empirical literature concerning entrepreneurship and business cycles in which nonlinearities are taken into consideration is not too extensive. Certainly, most previous works model the relationship implicitly or explicitly by means of a linear reaction function that assumes, by construction, symmetric behaviour over the different phases of the business cycle. There are two possible reasons why we should check for asymmetry. On the one hand, ignoring the existence of asymmetry when it is present leads to a mis-specified model, which produces bad forecasts and erroneous inferences in hypothesis testing. On the other hand, incorrect inferences delay the opportunity to obtain a correct calibration of policies. To avoid these problems, we are going to extend our benchmark equations by allowing for different effects among different regimes defined by the output growth data or the cyclical self-employment data.

For these two reasons, we apply a class of panel threshold models developed by Hansen (1999) to characterise the relationship between cyclical self-employment and output gap

\footnotetext{
${ }^{7}$ In Hartog et al. (2010), the effect of business ownership on GDP is contemporaneous, whereas the work of Carree and Thurik (2008) includes alternative lag structures. We argue that GDP growth may only have an impact on cyclical self-employment in future quarters/years. Because our analysis is focused on short-run impacts we will use a lag of one year for each variable in each equation for the lag structure. With regard to the reverse relationship, we will also argue that cyclical self-employment only has an impact on cyclical GDP after a certain amount of time since the start-up. We also assume a lag of one year.
} 
in which parameters vary not only across individuals but also with time, allowing for the presence of asymmetries in the self-employment dynamics over the business cycle or in the reverse relationship. The two models are now defined as follows:

$$
\begin{gathered}
s_{i t}^{c}=\mu_{i}^{\prime}+\beta_{y 0}^{\prime} y_{i t-1}^{c} I\left(d_{i t} \leq k\right)+\beta_{y 1}^{\prime} y_{i t-1}^{c} I\left(d_{i t}>k\right)+\beta_{u}^{\prime} u_{i t}^{c}+\varepsilon_{i t} ; \\
y_{i t}^{c}=\mu_{i}+\beta_{s 0} s_{i t-1}^{c} I\left(d_{i t} \leq k\right)+\beta_{s 1} s_{i t-1}^{c} I\left(d_{i t}>k\right)+\beta_{u} u_{i t}^{c}+\varepsilon_{i t},
\end{gathered}
$$

where $\mu_{i-1}$ is a fixed effect, $d_{i t}$ is the threshold variable, and $k$ is the threshold parameter. $I$ is the Heaviside indicator function, which equals 1 when the threshold condition is satisfied and 0 otherwise. In sum, in this model, the observations are divided into two regimes depending on whether the threshold variable $d_{i t}$ is smaller or greater than the threshold parameter $k$. The two regimes are distinguished by different regression slopes, $\beta_{0}$ and $\beta_{1}$.

However, there is no reason to impose only two regimes. A more general specification with $r$ thresholds will take the form of:

$$
\begin{aligned}
& s_{i t}^{c}=\mu_{i}^{\prime}+\beta_{y 0}^{\prime} y_{i t-1}^{c} I\left(d_{i t} \leq k_{1}\right)+\beta_{y 1}^{\prime} y_{i t-1}^{c} I\left(k_{1}<d_{i t} \leq k_{2}\right)+\ldots+ \\
& \beta_{y r}^{\prime} y_{i t-1}^{c} I\left(d_{i t}>k_{r}\right)+\beta_{u}^{\prime} u_{i t}^{c}+\varepsilon_{i t} \\
& y_{i t}^{c}=\mu_{i}+\beta_{s 0} s_{i t-1}^{c} I\left(d_{i t} \leq k_{1}\right)+\beta_{s 1} s_{i t-1}^{c} I\left(k_{1}<d_{i t} \leq k_{2}\right)+\ldots+ \\
& \beta_{s r} s_{i t-1}^{c} I\left(d_{i t}>k_{r}\right)+\beta_{u} u_{i t}^{c}+\varepsilon_{i t} .
\end{aligned}
$$

These two equations will be the benchmark for the estimates reported in the next section.

\section{Estimation and tests}

This section presents the empirical results for the bidirectional relationship between cyclical self-employment and output gaps represented by Equations (7a) and (7b) based on the two alternative threshold variables mentioned above. More specifically, we compare results from the use of lagged cyclical self-employment as the threshold variable with those based on the lagged cyclical output. The obtained empirical results are presented in two steps. First, we look for threshold variables. Second, we report estimates of the relationship between entrepreneurship and output for the different subsamples - regimes.

\subsection{Data}

As already mentioned, our goal is to verify whether the two-way relationship between output gap and cyclical self-employment exhibits nonlinear or asymmetric behaviour. To this end, we use a sample of over four decades of annual time-series data from 23 OECD countries. In particular, we use data from Australia, Canada, Iceland, Japan, New Zealand, Norway, Switzerland, the United States and the EU-15 for the period from 1972 to 2011. Entrepreneurship is operationalised in terms of self-employment, 
reflecting data availability at the time-series level. The business ownership rate (selfemployment rate) is the number of business owners divided by the total labour force. Business owners are defined as the total number of unincorporated and incorporated self-employed individuals outside the agriculture, hunting, forestry and fishing industries - see Van Stel (2005: 108). These data are taken from EIM's COMPENDIA database (version 2011.1). GDP is taken from OECD National Accounts and is measured in millions of US $\$$ at 2000 constant prices.

\subsection{Threshold variables}

The next step should be the estimation of panel transition regression models (7a) and (7b) in which the determination of the threshold variable plays a crucial role in the strategy. We consider two potential candidates: cyclical self-employment and output gap lagged by one period.

On the one hand, in Equation 7a (7b), it appears plausible that past cyclical self-employment influences regime switching: a higher cyclical self-employment rate (output growth) implies a different impact on cyclical output (cyclical self-employment) than a lower level if entrepreneurship exhibits decreasing marginal returns. On the other hand, it is also possible that the transitions are induced by the phase of the business cycle, which is one of the main hypotheses to be tested in this work. As usual in the estimation of panel threshold regression models, we discriminate between these two candidates according to a statistical criterion. In particular, we choose those variables that i) minimise the sum of squared residuals (Hansen 1999) and ii) lead to the strongest rejection of the linearity hypothesis as threshold variables.

After selecting the threshold variables, the estimation of the panel threshold regression model $^{8}$ defined by Equations (7a) and (7b) involves i) checking whether the threshold effect is statistically significant relative to a linear specification and, if this is the case, ii) determining the number of thresholds. In particular, the null hypothesis is tested through a likelihood ratio test ${ }^{9}$. This sequential process stops when the null is not rejected.

In our case, the results of both the linearity tests and the determination of the number of thresholds for models (7a) and (7b) are reported in Table 2. For the model described in Equation (7a), the $F_{1}$ linearity test clearly leads to the rejection of the null hypothesis of the linearity of the relationship between cyclical self-employment and the output gap, only when the lagged cyclical self-employment is the chosen threshold variable. This evidence corroborates the decision of estimating the relationship that runs from self-employment to output gap in a nonlinear form. The $F_{2}$ likelihood ratio test is also significant at the 10 and 1 percent levels for the lagged cyclical self-employment. This finding means that there are at least three regimes.

\footnotetext{
${ }^{8}$ Since the variables need to be stationary in order to run the panel threshold regression, unit root tests have been applied. The results shows that the cycles used are stationary. Results available upon request.

${ }^{9}$ In this test, the sum of the squared residuals of the specification with $r$ regimes is tested against the specification with $r+1$ regimes.
} 
Table 2. Linearity test and tests for threshold effects

\begin{tabular}{|c|c|c|c|c|}
\hline & \multicolumn{2}{|c|}{ Equation $7 \mathrm{a}$ (threshold variable) } & \multicolumn{2}{|c|}{ Equation $7 \mathrm{~b}$ (threshold variable) } \\
\hline & $y_{i t-1}^{c}$ & $s_{i t-1}^{c}$ & $y_{i t-1}^{c}$ & $s_{i t-1}^{c}$ \\
\hline \multicolumn{5}{|c|}{ Test for single threshold (two regimes) } \\
\hline RSS & 70.463 & 68.076 & 0.257 & 0.254 \\
\hline $\mathrm{F}_{1}$ & 9.431 & 37.946 & 5.531 & 16.316 \\
\hline p-value & 0.220 & 0.000 & 0.443 & 0.013 \\
\hline $\begin{array}{l}(10 \%, 5 \%, 1 \% \\
\text { critical values) }\end{array}$ & $\begin{array}{c}(12.470,15.504, \\
20.179)\end{array}$ & $\begin{array}{c}(9.813,12.422 \\
24.547)\end{array}$ & $\begin{array}{c}(9.722,11.809 \\
15.015)\end{array}$ & $\begin{array}{c}(7.274,8.236 \\
12.649)\end{array}$ \\
\hline \multicolumn{5}{|c|}{ Test for double threshold (three regimes) } \\
\hline RSS & & 66.452 & & 0.252 \\
\hline $\mathrm{F}_{2}$ & & 19.673 & & 4.702 \\
\hline p-value & & 0.000 & & 0.220 \\
\hline $\begin{array}{l}(10 \%, 5 \%, 1 \% \\
\text { critical values) }\end{array}$ & & $\begin{array}{c}7.628,9.895 \\
11.290)\end{array}$ & & $\begin{array}{c}6.411,7.675, \\
10.448)\end{array}$ \\
\hline \multicolumn{5}{|c|}{ Test for triple threshold (four regimes) } \\
\hline RSS & & 66.129 & & \\
\hline $\mathrm{F}_{3}$ & & 3.940 & & \\
\hline p-value & & 0.500 & & \\
\hline $\begin{array}{l}\text { (10\%, } 5 \%, 1 \% \\
\text { critical values) }\end{array}$ & & $\begin{array}{c}(8.443,10.354 \\
14.131)\end{array}$ & & \\
\hline
\end{tabular}

Notes: $F_{1}, F_{2}$ and $F_{3}$ are the likelihood ratio statistics. p-values are obtained with 300 simulations (Hansen 1999). RSS: Residuals Sum of Squared.

According to the procedure proposed by Hansen, it would be necessary in this case to estimate and test three thresholds, four thresholds and so on, until the corresponding F-test is statistically non-significant. Following this strategy, the $F_{3}$ likelihood ratio test is not statistically significant. Moreover, the presence of a strong threshold effect is detected when lagged self-employment is selected as a threshold variable. Therefore, the selected model is the one with three regimes, whose optimal threshold variable is cyclical self-employment lagged by one period, which minimises the sum of squared residuals.

Estimated threshold values for this three-regime model and the parameter estimates with the corresponding $t$-statistics are reported in Table 3. These parameters indicate when the switching between any of the three regimes occurs. For instance, if cyclical selfemployment is greater than -0.444 and less than 0.315 , the country concerned switches to the second regime. For cases in which the deviation between the observed and natural self-employment rates - in absolute values, i.e., extreme regimes - is higher, output gap and cyclical self-employment show a positive relationship. 
Table 3. Threshold estimates

\begin{tabular}{ccccc}
\hline & \multicolumn{2}{c}{ Model 7a } & Model 7b \\
\hline & Estimate & $95 \%$ Confidence interval & Estimate & $95 \%$ Confidence interval \\
\hline$\hat{\gamma}_{1}^{r}$ & -0.444 & {$[-0.445,-0.440]$} & -0.429 & {$[-0.445,0.398]$} \\
\hline$\hat{\gamma}_{2}^{r}$ & 0.315 & {$[0.240,0.478]$} & & \\
\hline
\end{tabular}

Table 4. Regression estimates of model

\begin{tabular}{cccc}
\hline \multicolumn{2}{c}{ Model 7a } & \multicolumn{2}{c}{ Model 7b } \\
\hline Regressor & Coefficient estimate & Regressor & Coefficient estimate \\
\hline$y_{i t}^{c} I\left(s_{i t-1}^{c} \leq-0.444\right)$ & $9.799^{* * *}$ & $s_{i t}^{c} I\left(s_{i t-1}^{c} \leq-0.429\right)$ & $0.017^{* * *}$ \\
& $(1.729)$ & $(0.005)$ \\
\hline \multirow{2}{*}{$y_{i t}^{c} I\left(0.315>s_{i t-1}^{c}>-0.444\right)$} & $-1.612^{* * *}$ & $s_{i t}^{c} I\left(s_{i t-1}^{c}>-0.429\right)$ & $-0.004^{*}$ \\
\hline$y_{i t}^{c} I\left(s_{i t-1}^{c}>0.315\right)$ & $(0.573)$ & $u_{i t}^{c}$ & $(0.002)$ \\
\hline \multirow{2}{*}{$u_{i t}^{c}$} & $3.549^{* * *}$ & & $-0.016^{* * *}$ \\
& $(1.160)$ & & \\
\hline
\end{tabular}

Note: Standard error in brackets. ${ }^{* * *}, * *$ and $*$ indicate significance at $1 \%, 5 \%$ and $10 \%$, respectively.

However, when the difference between the observed and natural self-employment rates is small in magnitude, in the second regime, the relationship becomes negative. Furthermore, and in light of these results, we note that the relationship between cyclical selfemployment and cyclical output (9.799) is stronger in the lowest and highest regimes (3.549). Conversely, the link is weaker in the intermediate regime (-1.612).

According to the estimated threshold values, we can deduce the distribution of the countries among the different regimes (Table A1 in the annex). We observe that the majority of observations are in the second regime, which corresponds to a negative relationship. Observations from Portugal, Greece and Ireland are often in the extreme regimes. We may observe once again that thresholds allow for heterogeneity and time instability to be taken into account. Consequently, effective counter-recessionary economic policies only could encourage entrepreneurship in the two extreme regimes.

For the model described in Equation $7 \mathrm{~b}$ in which output gap is the endogenous variable, the $F_{1}$ linearity test also leads to the rejection of the null hypothesis of linearity only in the case in which lagged cyclical self-employment is used as a threshold. As in model $7 \mathrm{a}$, the test indicates the convenience of estimating the model in nonlinear form with two regimes. Therefore, the selected model is the one with two regimes in which the optimal threshold variable is the lagged cyclical self-employment.

Threshold values for this model and the estimates of the parameters for the two regimes are reported in Tables 3 and 4, respectively. If lagged cyclical self-employment is greater than -0.429 , the country concerned switches to the second regime. If the deviation 
between the observed and natural self-employment rates is lower than -0.429 , a higher cyclical self-employment leads to a positive impact on cyclical output. The distribution of the countries among the different regimes and thresholds for different countries are presented in Table A1.

\section{Discussion}

We have tested whether the relation between entrepreneurship cycles (business creation) and business cycles is nonlinear. Estimating the two-way relationship and accounting for the possibility of nonlinear effects, the results qualify previous empirical studies and suggest that different types of effects prevail in different regimes. In short, the panel regression estimates from these regimes confirm that the two relationships are time-varying. For the first model, the intensity and sign of the output growth effect on cyclical self-employment in the two extreme regimes indicates the existence of a positive relationship between cyclical self-employment and the output gap, whereas a negative relationship characterises the second regime in which most of the observations are included. In terms of prior empirical literature, our findings are broadly consistent with previous studies which have related self-employment rates to aggregate economic performance (Fritsch, Mueller 2004; Thurik et al. 2008; Koellinger, Thurik 2012; Congregado et al. 2012; Parker et al. 2012). In particular, this paper has contributed to clarifying, to some extent, the puzzle in the literature on the cyclicality of self-employment. Testing for the presence of asymmetries in the relationships, our results suggest that the interplay between entrepreneurship and business cycles differs depending on the state of the self-employment sector. Importantly, rather than rejecting previous evidence, our results serve to qualify its scope.

\section{Conclusions}

On the basis of our results some tentative recommendations can be advanced for practitioners. In this respect, our results should be considered not only as evidence in favour of the positive effects of entrepreneurship policy in combating stagnation and unemployment but also with regard to the issue of how counter-recessionary economic policy at the macro level helps to encourage self-employment. Therefore, the favourable effects of entrepreneurship promotion policies on output growth are guaranteed when cyclical self-employment rates are notably lower than the equilibrium rates. This result is highly important in light of the current situation in many countries in which other policies are failing to combat unemployment and to recover sustainable growth paths.

In addition, the evidence provided also suggests that effective policies at the macro level are also good strategies for encouraging high-quality entrepreneurship in order to stimulate employment and innovation, but only when cyclical self-employment is in the two extreme regimes - i.e., when the deviation of the self-employment rate from its natural value reaches extreme values.

Nevertheless, despite the importance of our findings, we should not forget that selfemployment is not an unambiguously valid operationalization of entrepreneurship. This 
limitation should be borne in mind when interpreting the results. In this article, the operationalization has been dictated by data availability considerations being aware that we only can aspire to capture a partial and incomplete representation of the entrepreneurship concept. With this caveat in mind, the empirical interpretability of our results is likely restricted to the specialized domain of entrepreneurship operationalized in terms of self-employment. Nevertheless, the availability of long time series of alternative indicators capturing the different elements that entrepreneurship involves is a major challenge for further research. Then, future work might fruitfully apply the methodology used in this article to a broader concept of entrepreneurship, and should also seek to apply it to the analysis of the impact of entrepreneurship not only on the economic growth but also on job creation or poverty reduction.

\section{References}

Acs, Z. J.; Audretsch, D. B.; Braunerhjelm, P.; Carlsson, B. 2012. Growth and entrepreneurship, Small Business Economics 39: 289-300. http://dx.doi.org/10.1007/s11187-010-9307-2

Arellano, M.; Bond, S. 1991. Some tests of specification for panel data: Monte Carlo evidence and an application to employment equations, Review of Economic Studies 582: 277-297.

http://dx.doi.org/10.2307/2297968

Aubrey, M.; Bonnet, J.; Renou-Maissant, P. 2013. Business cycle and entrepreneurial behavior using French regional data. WP 2013-04. CREM, University of Caen and University of Rennes.

Audretsch, D. B.; Keilbach, M. C. 2004. Entrepreneurship capital and economic performance, Regional Studies 38: 949-59. https://doi.org/10.1080/0034340042000280956

Audretsch, D. B.; Carree, M. A.; van Stel, A. J.; Thurik, A. R. 2002. Impeded industrial restructuring: the growth penalty, Kyklos 55(1): 81-98.

http://dx.doi.org/10.1007/0-306-47556-1_1

Baumgartner, H. J.; Caliendo, M. 2008. Turning Unemployment into self-employment: effectiveness of two start-up programmes, Oxford Bulletin of Economics and Statistics 703: 346-373. http://dx.doi.org/10.1111/j.1468-0084.2008.00505.x

Binks, M.; Jennings, A. 1986. Small firms as a source of economics rejuvenation, in J. Curran, et al. (Eds.). The survival of small firms, Vol. 1. Gower: Aldershot.

Box, M.; Lin, X.; Gratzer, K. 2014. Linking entrepreneurship and economic growth in Sweden 1850-2000. PESO Working paper, School of Social Sciences, Sodertorn University

Carmona, M.; Congregado, E.; Golpe, A. A. 2010. Co-movement and causality between selfemployment, unemployment and business cycle in the EU-12, International Review of Entrepreneurship 84: 1-35.

Carmona, M.; Congregado, E.; Golpe, A. A. 2012. Comovement between self-employment and macroeconomic variables. evidence from Spain, SAGE Open 22: 1-7.

http://dx.doi.org/10.1177/2158244012448665

Carree, M. A.; Thurik, A. R. 2003. The impact of entrepreneurship on economic growth, in Z. J. Acs, D. B. Audretsch (Eds.). Handbook of entrepreneurship research. Dordrecht: Kluwer Academic, 437-471.

Carree, M. A.; Thurik, A. R. 2008. The lag structure of the impact of business ownership on economic performance in OECD countries, Small Business Economics 30: 101-110.

http://dx.doi.org/10.1007/s11187-006-9007-0 
Carree, M. A.; van Stel, A. J.; Thurik, A. R.; Wennekers, A. R. M. 2002. Economic development and business ownership: an analysis using data of 23 OECD countries in the period 1976-1996, Small Business Economics 193: 271-290. http://dx.doi.org/10.1023/A:1019604426387

Carree, M. A.; van Stel, A. J.; Thurik, A. R.; Wennekers, A. R. M. 2007. The relationship between economic development and business ownership revisited, Entrepreneurship and Regional Development 193: 281-291. http://dx.doi.org/10.1080/08985620701296318

Congregado, E.; Golpe, A. A.; Parker, S. C. 2012. The dynamics of entrepreneurship: hysteresis, business cycles and government policy, Empirical Economics 43: 1239-1261.

http://dx.doi.org/10.1007/s00181-011-0516-6

Cowling, M.; Mitchell, P. 1997. the evolution of U.K. self-employment: a study of government policy and the role of the macroeconomy, The Manchester School of Economic \& Social Studies 654: 427-442. http://dx.doi.org/10.1111/1467-9957.00073

Dejardin, M. 2011. Linking net entry to regional economic growth, Small Business Economics 36: 443-460. http://dx.doi.org/0.1007/s11187-009-9255-x

den Haan, W. J. 2000. The comovement between output and prices, Journal of Monetary Economics 46: 3-30. http://dx.doi.org/10.1016/S0304-3932(00)00016-7

Dumitrescu, E. I.; Hurlin, C. 2012. Testing for granger non-causality in heterogeneous panels, Economic Modelling 29(4): 1450-1460. http://dx.doi.org/10.1016/j.econmod.2012.02.014

Engle, R. F.; Granger, C. W. J. 1987. Cointegration and error correction: representation, estimation and testing, Econometrica 55: 251-276.

Erken, H.; Donselaar, P.; Thurik, A. R. 2008. Total factor productivity and the role of entrepreneurship. Jena Economic Research Papers No. 019. Jena: Max Planck Institute of Economics.

Fiess, N.; Fugazza, M.; Maloney, W. F. 2010. Informal self-employment and macroeconomic fluctuations, Journal of Development Economics 912: 211-226.

http://dx.doi.org/10.1016/j.jdeveco.2009.09.009

Fritsch, M.; Mueller, P. 2004. The effects of new business formation on regional development over time, Regional Studies 38: 961-975. https://doi.org/10.1080/0034340042000280965

Hansen, B. E. 1999. Threshold effects in non-dynamics panels: estimation, testing and inference, Journal of Econometrics 93: 345-368. http://dx.doi.org/10.1016/S0304-4076(99)00025-1

Hartog, C.; Parker, S.; van Stel, A.; Thurik, R. 2010. The two-way relationship between entrepreneurship and economic performance. EIM Business and Policy Research Scales Research Reports, No. H200822.

Hodrick, R.; Prescott, E. 1997. Postwar US Business cycles: an empirical investigation, Journal of Money, Credit, and Banking 29: 1-16.

Jaeger, A.; Parkinson, M. 1990. Testing for hysteresis in unemployment rates: an unobserved component approach, Empirical Economics 15: 185-198. http://dx.doi.org/10.1007/BF01973452

Johansen, S. 1988. Statistical analysis of cointegration vectors, Journal of Economic Dynamics and Control 12(2-3): 231-254. http://dx.doi.org/10.1016/0165-1889(88)90041-3

Johansen, S. 1991. Estimation and hypothesis testing of cointegration vectors in Gaussian vector autoregressive models, Econometrica 596: 1551-158.

Kao, C. 1999. Spurious regression and residual-based tests for cointegration in panel data, Journal of Econometrics 90: 1-44. http://dx.doi.org/10.1016/S0304-4076(98)00023-2

Koellinger, P.; Thurik, A.R. 2012. Entrepreneurship and the business cycle, Review of Economics and Statistics 944: 1143-1156. http://dx.doi.org/10.1162/REST_a_00224

Lamballais Tessensohn, T.; Thurik, A. R. 2012. The relation between different kinds of nascent entrepreneurship and the business cycle, in P. Braunerhjelm (Ed.). Entrepreneurship, norms and the business cycle. Örebro, Sweden: Swedish Entrepreneurship Forum, pp. 53-72. 
Li, H.; Yang, Z.; Yao, X.; Zhang, H.; Zhang, J. 2012. Entrepreneurship, private economy and growth: evidence from China, China Economic Review 234: 948-961.

http://dx.doi.org/ 10.1016/j.chieco.2012.04.015

Maddala, G.; Wu, S. 1997. On segmented multivariate regressions, Statistica Sinica 7: 497-525.

Parker, S. C. 1996. A time series model of self-employment under uncertainty, Economica 63: 459-475.

Parker, S. C. 2012. Theories of entrepreneurship, innovation and the business cycle, Journal of Economic Surveys 263: 377-394. http://dx.doi.org/10.1111/j.1467-6419.2012.00728.x

Parker, S. C.; Congregado, E.; Golpe, A. A. 2012. Is entrepreneurship a leading or lagging indicator of the business cycle? Evidence from UK self-employment data, International Small Business Journal 307: 736-753. http://dx.doi.org/10.1177/0266242612437560

Parker, S. C.; Robson, M. T. 2004. Explaining international variations in self-employment: evidence from a panel of OECD countries, Southern Economics Journal 71: 287-301.

Pedroni, P. 1999. Critical values for cointegration tests in heterogeneous panels with multiple regressors, Oxford Bulletin of Economics and Statistics 61: 653-670.

http://dx.doi.org/10.1111/1468-0084.0610s1653

Pedroni, P. 2000. Fully Modified OLS for heterogeneous cointegrated panels, in B. H. Baltagi (Ed.). Nonstationary panels, panel cointegration, and dynamic panels. Amsterdam: Elsevier.

Pedroni, P. 2004. Panel cointegration. asymptotic and finite sample properties of pooled time series tests with an application to the PPP hypothesis, Econometric Theory 20: 597-625.

http://dx.doi.org/10.1017/S0266466604203073

Pérez-Alonso, A.; Di Sanzo, S. 2011. Unemployment and hysteresis: a nonlinear unobserved components approach, Studies Nonlinear Dynamics and Economics 151(1): art.2.

http://dx.doi.org/10.2202/1558-3708.1806

Reynolds, P. D.; Camp, S. M.; Bygrave, W. D.; Autio, E.; Hay, M. 2001. The global entrepreneurship monitor, 2001 executive report. London Business School and Babson College.

Scholman, G.; van Stel, A.; Thurik, R. 2014. The relationship between entrepreneurial activity, the business cycle and economic openness. EIM Business and Policy Research Scales Research Reports, No. H201218.

Stam, E.; van Stel, A. J. 2009. Types of entrepreneurship and economic growth. UNU-MERIT Working Paper Series 049. United Nations University, Maastricht Economic and social Research and training centre on Innovation and Technology.

Thurik, A. R.; Carree, M. A.; van Stel, A. J.; Audretsch, D. B. 2008. Does self-employment reduce unemployment?, Journal of Business Venturing 236: 673-686.

http://dx.doi.org/10.1016/j.jbusvent.2008.01.007

Torrini, R. 2005. Cross-country differences in self-employment rates: the role of institutions, Labour Economics 12: 661-683. http://dx.doi.org/10.1016/j.labeco.2004.02.010

Van Stel, A. 2005. COMPENDIA: harmonizing business ownership data across countries and over time, International Entrepreneurship and Management Journal 11: 105-123.

http://dx.doi.org/10.1007/s11365-005-6678-y

Van Stel, A.; Carree, M.; Thurik, A. R. 2005. The effect of entrepreneurial activity on national economic growth, Small Business Economics 243: 301-321.

http://dx.doi.org/10.1007/s11187-005-1996-6

Van Stel, A.; Hartog, C.; Cieslik, J. 2010. Measuring business ownership across countries and over time: extending the COMPENDIA data base. EIM Business and Policy Research, Scales Research Reports, No. H201019. 
Van Stel, A.; Storey, D. J.; Thurik, A. R. 2007. The effect of business regulations on nascent and young business entrepreneurship, Small Business Economics 28: 171-186.

http://dx.doi.org/10.1007/s11187-006-9014-1

Wennekers, A. R. M.; van Stel, A. J.; Thurik, A. R.; Reynolds, P. D. 2005. Nascent entrepreneurship and the level of economic development, Small Business Economics 24: 293-309.

http://dx.doi.org/10.1007/s11187-005-1994-8

Wennekers, A. R. M.; Thurik, A. R.; van Stel, A. J.; Noorderhaven, N. 2007. Uncertainty avoidance and the rate of business ownership across 21 OECD countries, 1976-2004, Journal of Evolutionary Economics 17: 133-160. http://dx.doi.org/10.1007/s00191-006-0045-1

\section{APPENDIX}

Table A1. Data distribution between regimes and countries

\begin{tabular}{|c|c|c|c|c|c|}
\hline & \multicolumn{3}{|c|}{ Model a } & \multicolumn{2}{|c|}{ Model b } \\
\hline & Lower & Middle & Upper & Lower & Upper \\
\hline Australia & 3 & 28 & 9 & 4 & 36 \\
\hline Austria & 0 & 35 & 5 & 1 & 39 \\
\hline Belgium & 0 & 38 & 2 & 0 & 40 \\
\hline Canada & 3 & 31 & 6 & 3 & 37 \\
\hline Denmark & 1 & 38 & 1 & 1 & 39 \\
\hline Finland & 1 & 35 & 4 & 1 & 39 \\
\hline France & 0 & 39 & 1 & 0 & 40 \\
\hline Germany & 0 & 40 & 0 & 0 & 40 \\
\hline Greece & 8 & 25 & 7 & 7 & 33 \\
\hline Iceland & 5 & 27 & 8 & 4 & 36 \\
\hline Ireland & 2 & 34 & 4 & 3 & 37 \\
\hline Italy & 1 & 35 & 5 & 2 & 38 \\
\hline Japan & 0 & 40 & 0 & 0 & 40 \\
\hline Luxembourg & 0 & 40 & 0 & 0 & 40 \\
\hline The Netherlands & 0 & 39 & 1 & 0 & 40 \\
\hline New Zealand & 5 & 29 & 6 & 5 & 35 \\
\hline Norway & 4 & 30 & 6 & 4 & 36 \\
\hline Portugal & 8 & 20 & 12 & 8 & 32 \\
\hline Spain & 4 & 29 & 7 & 4 & 36 \\
\hline Sweden & 2 & 34 & 4 & 2 & 38 \\
\hline Switzerland & 1 & 35 & 4 & 1 & 39 \\
\hline United Kingdom & 5 & 30 & 5 & 5 & 35 \\
\hline United States & 0 & 39 & 1 & 0 & 40 \\
\hline
\end{tabular}

Note: The threshold variable is the cyclical self-employment lagged by one period. 
Mónica CARMONA. She is Senior Lecturer of Marketing and Head of the Department of Business Administration and Marketing. Her areas of interest are entrepreneurship, and applied economics.

Emilio CONGREGADO. He is Associate Professor in the Department of Economics. His field of research is the Economics of Entrepreneurship.

Antonio A. GOLPE. He is Associate Professor. His main research interests are in the area of applied economics.

Jesus IGLESIAS. He is Lecturer in Economics. His field of research is the Economics of Entrepreneurship. 